\begin{tabular}{|c|c|c|}
\hline 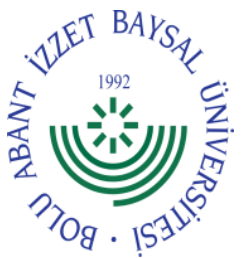 & $\begin{array}{l}\text { International Journal of Agriculture and Wildlife } \\
\qquad \text { Science } \\
\text { http://dergipark.org.tr/ijaws }\end{array}$ & 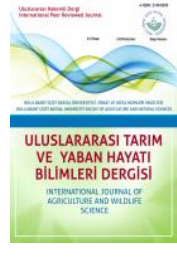 \\
\hline
\end{tabular}

Research Article

Potential of Local Entomopathogenic Nematode Isolates to Control the Adults of the Scarab Beetle, Epicometis hirta (Coleoptera: Scarabaeidae) ${ }^{*}$

\author{
Fatma Akpınar, Ebubekir Yüksel ${ }^{\star}$, Ramazan Canhilal \\ Department of Plant Protection, Faculty of Seyrani Agriculture, Erciyes University, Kayseri, Turkey
}

Geliş tarihi (Received): 23.06.2020 Kabul tarihi (Accepted): 21.07.2020

Keywords:
Scarab beetle, Steinernema
spp., Heterorhabditis spp.,
beneficial
biological nematodes,

*Corresponding author: ebubekiryuksel@erciyes.edu.tr

\begin{abstract}
The scarab beetle, Epicometis (Tropinota) hirta (Poda) (Coleoptera: Scarabaeidae), is a serious pest that feeds and destroys developing and blossoming flowers of apple plants. The pest has recently been reported more frequently from apple orchards in Turkey. The control of the adults of $E$. hirta is challenging due to the restrictions on the application of the chemicals used against the adults during the flowering period of apple orchards in Turkey. Other control methods fail to achieve desired results in the control of the adults. Therefore, there is an increasing need for more sustainable and environmentally-friendly control methods against the adults of E. hirta. In the present study, the pathogenicity of Turkish entomopathogenic nematode (EPN) isolates was evaluated using adults of this pest under laboratory conditions, toward developing an EPN-based integrated E. hirta control plan. Virulence of local EPN isolates against $E$. hirta was tested in 12-well bioassay plates containing sterile soil treated with different EPN concentrations $\left(0,190\right.$ and $380 \mathrm{Iss}^{\mathrm{J}}$ adult $\left.{ }^{-1}\right)$ and then incubated at 25 or $30{ }^{\circ} \mathrm{C}$. All the EPNs isolates caused high mortality ranging from 45 to $100 \%$ at $25{ }^{\circ} \mathrm{C}$, or 60 to $100 \%$ at $30^{\circ} \mathrm{C}$, respectively. The local Steinernema carpocapsae (Weiser) (Nematoda: Rhabditida) isolate E76-S from Turkey was the most efficient, achieving the maximum mortality rate (100\%) at both temperatures. The evidence of this study gave promising results for the control of the adults of E. hirta using local EPN isolates but further studies should be carried out in field conditions to determine the field performance of EPNs.
\end{abstract}

\title{
Yerel Entomopatojen Nematod İzolatlarının, Bakla Zınnı, Epicometis hirta (Coleoptera: Scarabaeidae) Erginlerini Kontrol Etme Potansiyeli
}

\begin{abstract}
Anahtar kelimeler:
Bakla zınnı, Steinernema spp., Heterorhabditis spp., faydalı nematodlar, biyolojik mücadele
\end{abstract}

Özet. Bakla Zınnı, Epicometis (Tropinota) hirta (Poda) (Coleoptera: Scarabaeidae), elma ağaçlarının tomurcuk ve açan çiçeklerinde beslenen ve ciddi tahribatlara neden olan önemli bir zararlıdır ve son zamanlarda Türkiye'deki elma bahçelerindeki artan bir sıklıkta bildirilmektedir. Türkiye'deki elma bahçelerinin çiçeklenme döneminde bu zararlıya karşı kullanılan kimyasalların uygulanmasına ilişkin kısıtlamalar nedeniyle $E$. hirta erginlerinin kontrolü oldukça zordur. Bu zararlıya karşı diğer mücadele yöntemleri kullanarak, E. hirta erginlerinin kontrolünde istenen sonuçları elde edilememektedir. Bu nedenle, E. hirta'nın erginlerine karşı daha sürdürülebilir ve çevre dostu kontrol yöntemlerine ihtiyaç artmaktadır. Bu çalışmada entomopatojen nematodların da içerisinde yer aldığı entegre bir mücadele programı oluşturulmasına yönelik, yerel entomopatojen nematod (EPN) izolatlarının E. hirta erginleri üzerindeki patojenisitesi laboratuvar koşulları altında değerlendirilmiştir. Yerel EPN izolatlarının E. hirta erginleri üzerindeki virülensi, farklı EPN konsantrasyonlarda $\left(0,190\right.$ ve $\left.380 \mathrm{IJ} \mathrm{ergin}^{-1}\right)$ ve sıcaklıkta (25 veya $\left.30{ }^{\circ} \mathrm{C}^{\prime} \mathrm{de}\right)$ içerisinde steril toprak bulunan (12) well-platelerde test edilmiştir. Test edilen EPN izolatları, $25^{\circ} \mathrm{C}^{\prime} \mathrm{de} \% 45-100$ ve $30^{\circ} \mathrm{C}$ 'de \%60-100 arasında değişen ölümlere neden olmuştur. Steinernema carpocapsae (Weiser) (Nematoda: Rhabditida) E76-S izolatı her iki sıcaklıkta da maksimum ölüm oranı (\%100) meydana getirerek en etkili izolat olmuştur. Bu çalışmanın sonuçları, yerel EPN izolatları kullanarak E. hirta erginlerinin kontrolü için umut verici sonuçlar vermiştir, ancak EPN'lerin arazi koşullarındaki etkinliğini belirlemek için arazi koşullarında çalışmalar yapılmasına ihtiyaç vardır. 


\section{INTRODUCTION}

The adults of the scarab beetle Epicometis (Tropinota) hirta (Poda) (Coleoptera: Scarabaeidae) is considered to be a serious pest of fruit tree orchards and frequently have been reported to infest blossom, feeding on petals, staminae and stigmae of flowers (Ertop and Özpinar, 2011), especially in European countries such as Austria (Böhm, 1950), Hungary (Toth et al., 2003), Bulgaria (Kutinkova and Andreev, 2004), Croatia (Ražov et al., 2009) and Macedonia (Rozner and Rozner, 2009). Recently, the damage of the adults of E. hirta on the various fruit trees in Turkey appears to be increasing (Tezcan and Pehlivan, 2001; Öztürk and Ulusoy, 2003; Özkan, 2005; Özbek, 2008; Yaşar et al., 2013; Arslan and Aslan, 2015; Gezer and Özpınar, 2015; Kaçar and Koca, 2020).

Turkey is one of the most important fruit tree growers in the world and over 85 fruit tree species are cultivated successfully (Ercisli, 2004). The adults of these beetles may damage $70 \%$ of the flowers of fruit trees, if not efficiently suppressed (Kutinkova and Andreev, 2004; Ražov et al., 2009). Recent restrictions imposed on the insecticides in the flowering period of fruit tree plants to protect the non-target organisms and the waiting period of the insecticides, as well as the potential of the adults of $E$. hirta to develop resistance to insecticides have led researchers to search for new and effective biological control strategies (Schmera et al., 2004; AbdelRazek, 2010; Abdel-Razek and Abd-Elgawad, 2013; Yaşar and Uysal, 2013; Al-Alawi, 2014; Atmaca et al., 2018; Özdemir and Gözel, 2018; Şahin et al., 2018; Aydin and Yaşar, 2019; Çolak et al., 2019; Özdemir et al., 2020; Şahin and Susurluk, 2020).

Entomopathogenic nematodes (EPNs) (Steinernema and Heterorhabditis sp.) have been receiving increasing attention in the last decades, due to their potential to control a wide range of pests of agricultural importance (Canhilal et al., 2007; Azizoglu et al., 2016; Canhilal et al., 2017; Kamali et al., 2017; Yuksel and Canhilal, 2018). The non-feeding stage of EPNs, infective juveniles (IJs), are capable of active host searching and killing the insect hosts within 24-72 $\mathrm{h}$ by the help of mutualistic bacteria mostly in the genera Xenorhabdus and Photorhabdus after penetrating host body (Poinar and Grewal, 2012; Stock et al., 2017Shan et al., 2019;). Although Alcaligenes sp. were isolated from $S$. carpocapsae there are still doubts about their symbiotic relationships with EPNs and pathogenicity against the insects (Boemare et al., 1996; Gouge and Snyder, 2016; Jiménez-Cortés et al., 2016; Fu and Lie, 2019; Shan et al., 2019; Özdemir et al., 2020).

Although the success of the foliar application of EPNs is limited compared to soil applications (Klein, 1990) they still possess a great potential to control foliage and cryptic pests. However, to be successful the right selection of application methods and time, species, isolate and temperature is important as these are among the most crucial factors affecting the efficacy of EPNs (Jacob and Mathew, 2016; Laleh et al., 2016; Begley et al., 2018; Hussein et al., 2019). Previous field studies showed that IJs of EPNs can remain alive and infective on the leaves and flowers of apple trees up to 4 days after application at dusk, which may be enough time-length for EPN-IJs to penetrate and kill large numbers of E. hirta pests in apple orchards (Bedding and Akhurst, 1975; Belair et al., 1998).

Laboratory evaluation of EPNs on the target pest is essential to indicate the control potential of the native species or isolates toward field studies. Thus, the efficacy of different EPN isolates (reported in Turkey) on the adults of E. hirta was established for varied IJ concentrations in EPN-treatments, dissimilar temperatures and increasing time-length of exposure of the adult E. hirta pests to the local EPN isolates under laboratory conditions. Our main objective was to predict at least a more promising local EPN isolate that may produce desirable results, if used, in field trials toward developing biocontrol strategy against the scarab beetle pest $(E$. hirta) in apple orchards in Turkey.

\section{MATERIAL AND METHOD}

\section{Obtaining Healthy Adults of E. hirta for Trial Under Laboratory Conditions}

Pesticide application in Kayseri province was stopped in June 2017 to secure and obtain sufficient numbers of healthy adults of $E$. hirta from the infested apple orchards. The collected adults were put in plastic cages $(20 \mathrm{x}$ $20 \times 25 \mathrm{~cm}^{3}$ ) with the lid opened to allow air. Blossoming apple flowers from these orchards were also added to the cages to provide food to the adult beetles. Few beetles were later transferred from the cages to a $180-\mathrm{ml}$ containers that lack food for beetle, and then examined for 24 hours under laboratory conditions at $25{ }^{\circ} \mathrm{C}$ and $60 \%$ relative humidity (R.H), to select the healthier adults for the experiments.

\section{In-vivo Production of Local EPN Isolates for Experiment}

Entomopathogenic nematode isolates (in Table 1) were produced using EPN-infected last instars of Galleria mellonella (L.) (Lepidoptera: Pyralidae) under laboratory conditions (i.e., at $25 \pm 1{ }^{\circ} \mathrm{C}$ and $60 \%$ R.H.) (Kaya and 

Curculionidae)

Gaugler, 1993; Canhilal, 2011; Yuksel et al., 2019). The IJ stock suspensions of each EPN isolate were rinsed into containers using distilled water and then stored at $7^{\circ} \mathrm{C}$ for one week before being used for laboratory trials.

One hour after the stock suspensions of each isolate were adjusted to active 190 and $380 \mathrm{IJs} / \mathrm{ml}$ according to the recommended IJ concentrations by Stock (2009), the EPNs were applied against E. hirta in bioassays using a micropipette.

Table 1. Native entomopathogenic nematode (EPN) isolates in Turkey.

Çizelge 1. Türkiye'den izole edilmiş yerel entomopatojen nematod (EPN) izolatları.

\begin{tabular}{lll}
\hline Isolates & Districts/Province & References \\
\hline Heterorhabditis indica 216-H & Afsin/Kahramanmaras & Canhilal et al., 2016 \\
H. bacteriophora FLH-4-H & Felahiye/Kayseri & Canhilal et al., 2017 \\
Steinernema bicornotum MGZ-4-S & Melikgazi/Kayseri & Canhilal et al., 2017 \\
S. carpocapsae E76-S & Tomarza/Kayseri & Canhilal et al., 2017 \\
S. feltiae KCS-4-S & Kocasinan/Kayseri & Canhilal et al., 2017 \\
\hline
\end{tabular}

\section{The Bioassay for the Laboratory Trial}

A flat bottom 12-well-plate was used for the experiment. A well in a plate has a surface area of $3.8 \mathrm{~cm} 2$ with its depth being $1.7 \mathrm{~cm}$. A $15 \mathrm{~g}$ sample of autoclaved air-dried sandy soil was added to each of the 12 wells per a plate. After that, a healthy-looking adult scarab beetle (E. hirta) was added in each well containing sandy soil. About a 5-g piece of apple flower as food was supplied to each beetle pest in each well before being treated with active IJs of the local EPN isolates.

\section{The EPN Isolate-Treatments to E. hirta in the Bioassay}

An adult beetle in each well was treated with $1 \mathrm{ml}$ of $190 \mathrm{IJs}$, using a micropipette. After inoculation of the beetles in all the 12 wells per plate, Parafilm was used to cover the surface of the wells to maintain moisture in each well. Similar EPN-treatment was done to E. hirta at the concentration of $1 \mathrm{ml}$ of $380 \mathrm{lJs} /$ adult in each of the 12 wells per plate. One millilitre of tap-water only was applied to an adult beetle in each of the 12 wells in a plate. Four replicates of a treatment in a 12-well-plate were made for each of the IJ concentrations 0,190 and $380 \mathrm{lJs} /$ adult, and then incubated at $25 \pm 1{ }^{\circ} \mathrm{C}$. Similarly, EPN-treatments at 0,190 and $380 \mathrm{IJs}$ adult-1 were made and then incubated at $30 \pm 1{ }^{\circ} \mathrm{C}$. The mortality of the adult beetle pests was assessed on $4^{\text {th }}, 8^{\text {th }}$ and $12^{\text {th }}$ days after treatment (DAT). A dead adult of $E$. hirta was retrieved from each well and the presence of IJs in the cadavers was done to confirm "mortality due to EPN" by examining a dissected cadaver under a microscope.

\section{Data Analysis}

Because none of the adult beetles died in the control, mortality of E. hirta observed in EPN isolatetreatments was not corrected before analysis. The SPSS-software (Version 11.0) was used to compute all statistics. The multiple analysis of variance (MANOVA) was used to examine whether manipulating IJ concentration of an EPN isolate in EPN-treatments, the number of EPN isolates used in the trials and level of temperature may cause a significant variation in their observed mean ( \pm standard error) values of the mortality of the scarab beetles at each DAT (Gotelli and Ellison, 2013). Tukey's multiple range tests at $P \leq 0.05$ were used to compare mean ( \pm standard error) values of mortality (the response variables) among the predicting treatment factors.

\section{RESULTS AND DISCUSSION}

All native EPN isolates tested were capable of infecting and killing the adults of $E$. hirta with varying levels of pathogenicity at both temperatures tested (Tables 2 and 3). The mortality rates of the adults were significantly influenced by the nematode isolates and concentrations of IJS as main factors at all time-lengths after EPNtreatment, whereas the temperature was significantly different only on the 4th and 8th DAT (Table 2). The effect of the interactions of the main factors on the mean mortality rates was not significant for the majority of the DAT (Table 2). Increasing the nematode concentration and temperature yielded an increase in the mortality rates of E. hirta (Table 3). Similarly, the mortality of E. hirta in all the treatments tended to increase with extension of exposure time to the EPNs. 
Akpınar et al., Evaluation of Turkish Isolates of Entomopathogenic Fungi Against The Adults of Sitophilus oryzae (L.) (Coleoptera: Curculionidae)

Table 2. MANOVA parameters for the main effects and associated interactions for the mortality rates of the adults of Epicometis hirta.

Çizelge 2. Epicometis hirta erginlerinin ölüm oranları için ana faktörler ve interaksiyonlarının çok değişkenli varyans analizi (MANOVA).

\begin{tabular}{|c|c|c|c|c|c|c|c|c|c|}
\hline \multirow{2}{*}{ Source* } & \multicolumn{3}{|c|}{$4^{\text {th }}$ DAT } & \multicolumn{3}{|c|}{$8^{\text {th }}$ DAT } & \multicolumn{3}{|c|}{$12^{\text {th }}$ DAT } \\
\hline & df & $\mathbf{F}$ & $\mathbf{P}$ & df & $\mathbf{F}$ & $\mathbf{P}$ & df & $\mathbf{F}$ & $\mathbf{P}$ \\
\hline$N$ & 4 & 7.429 & 0.000 & 4 & 9.158 & 0.000 & 4 & 5.769 & 0.000 \\
\hline C & 1 & 482.187 & 0.000 & 1 & 1.224 .516 & 0.000 & 1 & 2.315 .263 & 0.000 \\
\hline $\mathrm{T}$ & 1 & 11.929 & 0.001 & 1 & 6.579 & 0.012 & 1 & 3.857 & 0.053 \\
\hline$N * T$ & 4 & 3.945 & 0.005 & 4 & 2.474 & 0.050 & 4 & 0.729 & 0.575 \\
\hline $\mathrm{N}^{*} \mathrm{C}$ & 4 & 2.566 & 0.014 & 4 & 2.424 & 0.020 & 4 & 1.127 & 0.353 \\
\hline$C * T$ & 1 & 4.071 & 0.020 & 1 & 1.274 & 0.285 & 1 & 1.594 & 0.209 \\
\hline$N^{*} C^{*} T$ & 4 & 2.015 & 0.053 & 4 & 1.471 & 0.179 & 4 & 0.973 & 0.462 \\
\hline
\end{tabular}

*DAT: Days after EPN-treatment, N: Number of local EPN isolates, C: Different EPN-IJ concentrations, T: Dissimilar temperatures, F: F-statistic, P: Probability for significant level and df: the degree of freedom. *Calculated P-value $\leq 0.05$ indicates that the source of variation in mortality of adult $E$. hirta was significant.

On the $12^{\text {th }}$ DAT, $100 \%$ mortality of adult beetles was achieved by the local $S$. carpocapsae isolate at both temperatures on the $12^{\text {th }}$ DAT (Table 3), but the least efficient isolate was the native S. feltiae (in Tables 2 and 3 ) that caused $45 \%$ and $60 \%$ mortality at $25 \pm 1$ and $30 \pm 1{ }^{\circ} \mathrm{C}$, respectively. On the $4^{\text {th }}$ DAT, the $S$. carpocapsae isolate (in Tables 2 and 3) had already caused $80 \%$ mortality at a concentration of $190 \mathrm{IJs}$ at $25^{\circ} \mathrm{C}$, whereas the remaining EPN isolate-treatments with $190 \mathrm{IJs} /$ adult at $25^{\circ} \mathrm{C}$ could only achieve very low mortalities ranging from $45 \pm 10$ to $57 \pm 17 \%$ (Table 3 ).

Table 3. The mortality rates (Mean $\pm \mathrm{Se}$ ) of the adults of Epicometis hirta exposed to different species of entomopathogenic nematodes, at two different concentrations of infective juveniles (IJs) in the well plates at $25 \pm 1{ }^{0} \mathrm{C}$ or $30 \pm 1{ }^{0} \mathrm{C}$. Çizelge 3. Farklı entomopatojen nematode izolatlarının iki farklı sıcaklikta $\left(25 \pm 1^{\circ} \mathrm{C}\right.$ ve $\left.30 \pm 7^{\circ} \mathrm{C}\right)$ ve konsantrasyonda (190 ve $380 \mathrm{lJs} /$ ergin) well-plate denemelerinde uygulamadan sonraki 4., 8 ve 12. günlerde Epicometis hirta erginleri üzerinde meydana getirdikleri ölüm oranları.

\begin{tabular}{|c|c|c|c|c|c|c|}
\hline \multirow{3}{*}{$\begin{array}{l}\text { Nematode } \\
\text { Isolates } \\
\text { /temperature* }\end{array}$} & \multicolumn{6}{|c|}{ Days after treatment (DAT) } \\
\hline & \multicolumn{2}{|c|}{$4^{\text {th }}$ day } & \multicolumn{2}{|c|}{$8^{\text {th }}$ day } & \multicolumn{2}{|c|}{$12^{\text {th }}$ day } \\
\hline & $\begin{array}{l}190 \\
\text { IJs/adult }\end{array}$ & 380 IJs/adult & 190 IJs/adult & $380 \mathrm{IJs} /$ adult & 190 IJs/adult & $\begin{array}{l}380 \\
\text { IJs/adult }\end{array}$ \\
\hline \multicolumn{7}{|l|}{$25^{\circ} \mathrm{C}$} \\
\hline MGZ-4S & $47 \pm 20 \mathrm{Aa}$ & $60 \pm 13 \mathrm{Bab}$ & $70 \pm 11 \mathrm{Aab}$ & $82 \pm 17 \mathrm{Bb}$ & $87 \pm 15 \mathrm{Ab}$ & $92 \pm 9 \mathrm{Bb}$ \\
\hline KCS-4S & $45 \pm 10 \mathrm{Aa}$ & $40 \pm 8 \mathrm{Aa}$ & $65 \pm 12 \mathrm{Ab}$ & $65 \pm 19 \mathrm{Ab}$ & $87 \pm 9$ Ac & $77 \pm 5 \mathrm{Abc}$ \\
\hline E-76-S & $80 \pm 8 \mathrm{Ba}$ & $87 \pm 15$ Cab & $95 \pm 5 \mathrm{Bb}$ & $92 \pm 9 \mathrm{Bb}$ & $100 \pm 0 \mathrm{Bb}$ & $95 \pm 10 \mathrm{Bb}$ \\
\hline $216-\mathrm{H}$ & $50 \pm 14 \mathrm{Aa}$ & $85 \pm 10 \mathrm{Cb}$ & $92 \pm 9 \mathrm{Bb}$ & $90 \pm 8 \mathrm{Bb}$ & $95 \pm 10 \mathrm{ABb}$ & $90 \pm 8 \mathrm{Bb}$ \\
\hline FLH-4-H & $57 \pm 17 \mathrm{Aa}$ & $72 \pm 17 \mathrm{BCb}$ & $85 \pm 5 A B C$ & $87 \pm 9 \mathrm{Bc}$ & $95 \pm 11 A B C$ & $95 \pm 10 \mathrm{BC}$ \\
\hline \multicolumn{7}{|l|}{$30^{\circ} \mathrm{C}$} \\
\hline MGZ-4S & $77 \pm 9 \mathrm{Aa}$ & $82 \pm 9 \mathrm{Ca}$ & $95 \pm 5 \mathrm{Bb}$ & $90 \pm 11 \mathrm{Bb}$ & $95 \pm 5 \mathrm{ABb}$ & $97 \pm 5 \mathrm{Bb}$ \\
\hline KCS-4S & $60 \pm 8 \mathrm{ABa}$ & $67 \pm 5 \mathrm{Ba}$ & $75 \pm 12 \mathrm{Aab}$ & $85 \pm 12 \mathrm{Bb}$ & $85 \pm 5 \mathrm{Ab}$ & $92 \pm 9 \mathrm{Bb}$ \\
\hline E-76-S & $70 \pm 8 \mathrm{Ba}$ & $80 \pm 8$ Cab & $92 \pm 9 \mathrm{Bb}$ & $95 \pm 5 \mathrm{Bb}$ & $100 \pm 0 \mathrm{Bb}$ & $100 \pm 0 \mathrm{Bb}$ \\
\hline $216-\mathrm{H}$ & $70 \pm 8 \mathrm{Ba}$ & $75 \pm 12 \mathrm{BCa}$ & $90 \pm 11 \mathrm{Bb}$ & $92 \pm 5 \mathrm{Bb}$ & $95 \pm 10 \mathrm{ABb}$ & $95 \pm 5 \mathrm{Bb}$ \\
\hline FLH-4-H & $75 \pm 12 \mathrm{Ba}$ & $75 \pm 12 \mathrm{BCa}$ & $85 \pm 5 \mathrm{ABb}$ & $85 \pm 12 \mathrm{Bb}$ & $90 \pm 8 \mathrm{ABb}$ & $92 \pm 9 \mathrm{Bb}$ \\
\hline
\end{tabular}

*Mean values followed by different lowercase letters in the same line and mean values followed by different uppercase letters in the same column are statistically different according to Tukey's test $(P \leq 0.05)$. FLH-4-H: Heterorhabditis bacteriophora, 216-H: H. indica, E76-S: Steinernema carpocapsae, MGZ-4-S: S. bicornotum, KCS-4S: S. feltiae.

Mortalities of adult E. hirta beetles observed in the S. feltiae isolate-treatments at 190 or $380 \mathrm{IJs}$ adult-1 mostly increased marginally with increasing DAT (Tables 2 and 3). Nonetheless, the $380 \mathrm{IJs}^{\text {adult }}{ }^{-1}$ of $S$. bicornotum, $\mathrm{H}$. indica and $\mathrm{H}$. bacteriophora isolates in the treatments at $30 \pm 1{ }^{\circ} \mathrm{C}$ achieved high mortality rates of E. hirta pests, similar to those observed for the $190 \mathrm{IJs}$ adult-1 of $\mathrm{S}$. carpocapsae isolate in treatments at $25 \pm 1^{\circ} \mathrm{C}$ (Tables 2 and 3).

This study showed that pathogenicity of EPNs to E. hirta varies depending on EPN species, the concentration of IJs, increasing time-length of exposing E. hirta to local EPN isolates, and temperature. The effectiveness of some species remained the same, or even decreased with the increasing concentration and temperature. 
Steinernema carpocapsae (a native isolate from Tomarza/Kayseri Province of Turkey) was the most outperforming pathogenic isolate among other local virulent EPNs tested against the adults of $E$. hirta, in this study. The higher efficacy of S. carpocapsae E-76 isolate could be due to the insect-killing symbiotic bacteria associated with it and its ambushing-to-cruising foraging strategy which helps them to reach the target insect (Lacey and Georgis, 2012; Campos-Herrera, 2015). In general, all the EPN isolates caused higher mortality to the adults of $E$. hirta starting from the fourth day after EPN-treatments, suggesting the need to select the more promising local EPN isolate(s) observed in this study for field trials against $E$. hirta in apple orchards. Principles to use these local EPN isolates against $E$. hirta in Turkey must be established, perhaps, similar to the way they were examined for the control of an Anastrepha fruit fly pest in guava orchards (Heve et al., 2016; 2017; 2018).

This is primarily because pathogenicity of EPNs, which high efficiency of the species against the $E$. hirta pest on blossoming flowers of apple trees may vary between laboratory and field environments. Thus, additional studies are needed to reveal the potential of the more virulent local EPN isolate(s) in apple orchards toward making rational decisions, even though these native isolates have established in Turkey where they are better adapted to changing climatic conditions.

\section{CONCLUSION}

In the present study, all local EPN isolates caused between 45 and $80 \%$ mortality within the first $96 \mathrm{~h}$ after inoculation. Obtained results are promising for field studies of EPNs to control the adults of E. hirta considering their surviving ability on the apple trees for 4 days after application (Belair et al., 1998). Further studies are needed to reveal the field potential of EPNs in apple orchards. Biotechnical methods such as colour and attractant traps may be used to enhance the efficiency of EPNs and provide better control.

\section{CONFLICT OF INTEREST}

The authors declare that they have no conflict of interest.

\section{AUTHORS' CONTRIBUTIONS}

FA, EY and RC conceived and designed the research. FA and EY conducted the experiments. FA and EY analyzed the data and wrote the manuscript. All authors read and approved the manuscript.

\section{REFERENCES}

Abdel-Razek, A. S. (2010). Field evaluation of bacterial symbionts of entomopathogenic nematodes for suppression of hairy rose beetle, Tropinota squalida Scop., (Coleoptera: Scarabaeidae) population on cauliflower in Egypt. Archives of Phytopathology and Plant Protection, 43(1), 18-25.

Abdel-Razek, A. S., \& Abd-Elgawad, M. M. M. (2013). Effects of entomopathogenic nematodes on suppressing hairy rose beetle, Tropinota squalida Scop. (Coleoptera: Scarabaeidae) population in cauliflower field in Egypt. International Scholarly and Scientific Research \& Innovation, 7, 28-32.

Al-Alawi, M. S. (2014). Efficacy of essential oils from medicinal plants in control of the hairy rose beetle, Tropinata squalida (Scopoli) and their comparative toxicity to the honey bee, Apis mellifera L. American Journal of Agricultural and Biological Sciences, 9(3), 284-288.

Arslan, Ö. M., \& Aslan, M. M. (2015). Kahramanmaraş ili badem ağaçlarında bakla zınnı (Epicometis hirta (Poda) (Coleoptera: Scarabaeidae)'nın farklı tuzaklarla yakalanması üzerine araştırma. Kahramanmaraş Sütçü Imam University Journal of Natural Sciences, 18(4), 6-12.

Atmaca, S., Pekbey, G., \& Canhilal, R. (2018). Bazı entomopatojen fungusların baklazınnı, Epicometis hirta (Poda) (Coleoptera: Scarabaeidae) erginlerine karşı virülensliği. Iğdır Üniversitesi Fen Bilimleri Enstitüsü Dergisi, 8(2), 37-42.

Azizoglu, U., Karabörklü, S., Ayvaz, A., \& Yilmaz, S., (2016). Phylogenetic relationships of insect-associated free-living Rhabditid nematodes from Eastern Mediterranean Region of Turkey. Applied Ecology and Environmental Research, 14(3), 93-103.

Bedding, R. A., \& Akhurst, R. J. (1975). A simple technique for the detection of insect paristic rhabditid nematodes in soil. Nematologica, 21(1), 109-110.

Belair, G., Vincent, C., \& Chouinard, G., (1998). Foliar sprays with Steinernema carpocapsae against early-season apple pests. Journal of Nematology, 30(4S), 599. 
Akpınar et al., Evaluation of Turkish Isolates of Entomopathogenic Fungi Against The Adults of Sitophilus oryzae (L.) (Coleoptera: Curculionidae)

Boemare, N., Laumond, C., \& Mauleon, H. (1996). The entomopathogenic nematode-bacterium complex: biology, life cycle and vertebrate safety. Biocontrol Science and Technology, 6(3), 333-346.

Boemare, N., Givaudan, A., Brehelin, M., \& Laumond, C., (1997). Symbiosis and pathogenicity of nematode-bacterium complexes. Symbiosis, 22(1-2), 21-45.

Böhm, H. (1950). Observations on the occurrence of Epicometis hirta injuring fruit blossom in Austria. Pflanzenschutzberichte, 5, 241-257.

Campos-Herrera, R. (2015). Nematode Pathogenesis of Insects and Other Pests: Ecology and Applied Technologies for Sustainable Plant and Crop Protection. Springer, Newyork, USA.

Canhilal, R., Reid, W., Kutuk, H., \& El-Bouhssini, M. (2007). Susceptibility of sunn pest, Eurygaster integriceps Puton (Hemiptera: Scutelleridae), to various entomopathogenic nematodes (Rhabditida: Steinernematidae and Heterorhabditidae). Journal of Agricultural and Urban Entomology, 24(1), $19-26$.

Canhilal, R. (2011). Heterorhabdit nematodların (rhabditida: heterorhabditidae) biyolojik etkinliklerinin Galleria mellonella L. (lepidoptera: pyralidae) üzerinde karşılaştırılması. Gaziosmanpaşa Üniversitesi Ziraat Fakültesi Dergisi, (2), 43-51.

Canhilal, R., Waeyenberge, L., Toktay, H., Bozbuga, R., Çerintas, R., \& Imren, M. (2016). Distribution of Steinernematids and Heterorhabditids (Rhabditida: Steinernematidae and Heterorhabditidae) in the Southern Anatolia Region of Turkey. Egyptian Journal of Biological Pest Control, 26(4).

Canhilal, R., Waeyenberge, L., Yüksel, E., Koca, A. S., Deniz, Y., \& Imren, M. (2017). Assessment of the natural presence of entomopathogenic nematodes in Kayseri soils, Turkey. Egyptian Journal of Biological Pest Control, 27(2).

Çolak, E. Ş., Yüksel, E., \& Canhilal, R. (2019). Yabancı otların kontrolünde biyolojik mücadele. Erciyes Tarım ve Hayvan Bilimleri Dergisi, 2(3), 23-29.

Ercisli, S., (2004). A short review of the fruit germplasm resources of Turkey. Genetic Resources and Crop Evolution, 51(4), 419435.

Ertop, S., \& Özpinar, A. (2011). Çanakkale ili kiraz ağaçlarındaki fitofag ve yararlı türler ıle bazı önemli zararlıların popülasyon değişimi. Türkiye Entomoloji Bülteni, 1(2), 109-118.

Fu, J. R., \& Liu, Q. Z. (2019). Evaluation and entomopathogenicity of gut bacteria associated with dauer juveniles of Oscheius chongmingensis (Nematoda: Rhabditidae). MicrobiologyOpen, 8(9), e00823.

Gaugler, R. (2018). Entomopathogenic Nematodes in Biological Control. CRC Press, New York, USA.

Gezer, B., \& Özpınar, A. (2015). Çanakkale ilinde şeftali, elma, kiraz ve kayısılarda Tropinota hirta (Poda) (Coleoptera: Cetoniidae) ergin yoğunluğunu belirlemede farklı tuzakların değerlendirilmesi. Çanakkale Onsekiz Mart Üniversitesi Ziraat Fakültesi Dergisi, 3(2), 27-34.

Gotelli, N. J., \& Ellison, A. M. (2013). The analysis of multivariate data. In N. J. Gotelli, \& A. M. Ellison (Eds.), A primer of ecological statistics, 2nd edition (pp. 384-445). Sunderland, Sinauer Associates, Inc. Publishers.

Gouge, D. H., \& Snyder, J. L. (2006). Temporal association of entomopathogenic nematodes (Rhabditida: Steinernematidae and Heterorhabditidae) and bacteria. Journal of Invertebrate Pathology, 91(3), 147-157.

Grewal, P. S., Lewis, E. E., Gaugler, R., \& Campbell, J. F. (1994). Host finding behaviour as a predictor of foraging strategy in entomopathogenic nematodes. Parasitology, 108(2), 207-215.

Heve, W. K., El-Borai, F. E., Carrillo, D., \& Duncan, L. W. (2016). Biological control potential of entomopathogenic nematodes for management of Caribbean fruit fly, Anastrepha suspensa Loew (Tephritidae). Pest Management Science, 73(6), 12201228.

Heve, W. K., El-Borai, F.E., Carrillo, D., \& Duncan, L.W. (2017). Increasing entomopathogenic nematode biodiversity reduces efficacy against the Caribbean fruit fly Anastrepha suspensa: interaction with the parasitoid Diachasmimorpha longicaudata. Journal of Pest Science, 91(2), 799-813.

Heve, W. K., El-Borai, F. E., Johnson, E.G., Carrillo, D., Crow, W. T., \& Duncan, L.W. (2018). Responses of Anastrepha suspensa, Diachasmimorpha longicaudata and sensitivity of guava production to Heterorhabditis bacteriophora in fruit fly integrated pest management. Journal of Nematology, 50(3), 261-272.

Hussein, M. A., \& El-Mahdi, I. F. (2019). Efficiency of three formulated entomopathogenic nematodes against onion thrips, Thrips tabaci under aquaculture system. Journal of Biopesticides, 12(1), 134-138.

Jacob, J. S., \& Mathew, M. P. (2016). Laboratory evaluation of entomopathogenic nematodes against American serpentine leaf miner, Liriomyza trifolii (Burgess). Journal of Biopesticides, 9(1), 27-33. 
Akpınar et al., Evaluation of Turkish Isolates of Entomopathogenic Fungi Against The Adults of Sitophilus oryzae (L.) (Coleoptera: Curculionidae)

Jiménez-Cortés, J. G., Canales-Lazcano, J., Lara-Reyes, N., Rosenblueth, M., Martínez-Romero, E., \& Contreras-Garduño, J. (2016). Microbiota from Rhabditis regina may alter nematode entomopathogenicity. Parasitology research, 115(11), 4153-4165.

Kacar, G., \& Koca, A. S. (2020). Bolu ili kiraz ve vişne bahçelerinde belirlenen zararlı ve faydalı türler. Uluslararası Tarım ve Yaban Hayatı Bilimleri Dergisi, 6(3), in press.

Kamali, S., Karimi, J., \& Koppenhöfer, A. M. (2018). New insight into the management of the tomato leaf miner, Tuta absoluta (Lepidoptera: Gelechiidae) with entomopathogenic nematodes. Journal of Economic Entomology, 111(1), 112-119.

Kaya, H. K., \& Gaugler, R. (1993). Entomopathogenic nematodes. Annual Review of Entomology, 38(1), 181-206.

Kutinkova, H., \& Andreev, R. (2004). Integrated pest management in sweet cherry (Prunus avium L.) orchards in Bulgaria. Journal of Fruit and Ornamental Plant Research, 12, 41-47.

Laleh, E., Shiri, M. R., \& Dunphy, G. B. (2016). Efficacy of the entomopathogenic nematode, Steinernema feltiae Against the vegetable leaf miner, Liriomyza sativae Blanchard (Diptera: Agromyzidae). Egyptian Journal of Biological Pest Control, 26(3), 583.

Özbek, H., (2008). Türkiye'de iliman iklim meyve türlerini ziyaret eden böcek türleri. Uludağ Arıcılı Dergisi, 8(3), 92-103.

Ozdemir, E., \& Gozel, U. (2018). Nematicidal activities of essential oils against Meloidogyne incognita on tomato plant. Fresenius Environmental Bulletin, 27(6), 4511-4517.

Özdemir, E., İnak, E., Evlice, E., \& Laznik, Z. (2020). Compatibility of entomopathogenic nematodes with pesticides registered in vegetable crops under laboratory conditions. Journal of Plant Diseases and Protection, 127, 529-535.

Özdemir, E., Bayram, Ş., \& Susurluk, İ. A. (2020). First Record of the Entomopathogenic Nematode Steinernema litorale (Filipjev) (Rhabditida: Steinernematidae) and Its Symbiotic Bacterium from Turkey, and Its Efficacy Capability. Insects, 11(3), 144.

Özkan, C., (2005). Çubuk (Ankara) ilçesi vişne ağaçlarında zararlı olan türler, doğal düşmanları ve önemlileri üzerinde gözlemler. Tarım Bilimleri Dergisi, 11(1), 57-59.

Öztürk, N., \& Ulusoy, M. R. (2003). Mersin ili kayısılarında saptanan zararlılar. Alatarım Dergisi, 2(2), 21-26.

Poinar, G. O., \& Grewal, P. S. (2012). History of entomopathogenic nematology. Journal of Nematology, 44, $153-61$.

Rozner, I., \& Rozner, G. (2009). Data to the Lamellicornia fauna of the Republic of Macedonia (Coleoptera: Lamellicornia). Natura Somogyiensis, 15, 57-68.

Ražov, J., BaRić, B., \& Dutto, M. (2009). Fauna of the Cetoniid beetles (Coleoptera: Cetoniidae) and their damages on peach fruits in orchards of Northern Dalmatia, Croatia. Entomologia Croatica, 13(2), 7-20.

Schmera, D., Tóth, M., Subchev, M., Sredkov, I., Szarukán, I., Jermy, T., \& Szentesi, A. (2004). Importance of visual and chemical cues in the development of an attractant trap for Epicometis (Tropinota) hirta Poda (Coleoptera: Scarabaeidae). Crop Protection, 23(10), 939-944.

Shan, S., Wang, W., Song, C., Wang, M., Sun, B., Li, Y., Fu, Y., Gu, X., Ruan, W., \& Rasmann, S. (2019). The symbiotic bacteria Alcaligenes faecalis of the entomopathogenic nematodes Oscheius spp. exhibit potential biocontrol of plant- and entomopathogenic fungi. Microbial Biotechnology, 12(3), 459-471.

Stock, S. P. (2009). Field Manual of Techniques in Invertebrate Pathology. Journal of Economic Entomology, 102(4), 17261726.

Stock, S. P., Kusakabe, A., \& Orozco, R. A. (2017). Secondary metabolites produced by Heterorhabditis symbionts and their application in agriculture: what we know and what to do next. Journal of Nematology, 49(4), 373-83.

Şahin, Y. S., Boucharı, A., Ulu, T. C., Sadıç, B., \& Susurluk, A. (2018). New application method for entomopathogenic nematode Heterorhabditis bacteriophora (Poinar, 1976)(Rhabditida: Heterorhabditidae) HBH strain against Locusta migratoria (Linnaeus, 1758)(Orthoptera: Acrididae). Türkiye Entomoloji Dergisi, 42(4), 305-312.

Şahin, Y. S., \& Susurluk, İ. A. (2020). The control of Turkestan Cockroach Blatta lateralis (Dictyoptera: Blattidae) by the entomopathogenic nematode Heterorhabditis bacteriophora $\mathrm{HBH}$ (Rhabditida: Heterorhabditidae) using hydrophilic Fabric Trap. Türk Tarım ve Doğa Bilimleri Dergisi, 7(2), 375-380.

Shan, S., Wang, W., Song, C., Wang, M., Sun, B., Li, Y., Fu, Y., Gu, X., Ruan, W. \& Rasmann, S. (2019). The symbiotic bacteria Alcaligenes faecalis of the entomopathogenic nematodes Oscheius spp. exhibit potential biocontrol of plant-and entomopathogenic fungi. Microbial Biotechnology, 12(3), 459-471.

Tezcan, S., \& Pehlivan, E. (2001). Evaluation of the Lucanoidea and Scarabaeoidea (Coleoptera) fauna of ecological cherry orchards in İzmir and Manisa provinces of Turkey. Ege Üniversitesi Ziraat Fakültesi Dergisi, 38(2-3), 31-37. 
Akpınar et al., Evaluation of Turkish Isolates of Entomopathogenic Fungi Against The Adults of Sitophilus oryzae (L.) (Coleoptera: Curculionidae)

Toth, M., Klein, M. G., \& Imrei, Z. (2003). Field screening for attractants of scarab (Coleoptera: Scarabaeidae) pests in Hungary. Acta Phytopathologica et Entomologica Hungarica, 38(3-4), 323-331.

Yaşar, B., Çeşme, İ., Baydar, M. S., Aysal, İ., \& Yazır, A. B. (2013). Farklı mavi renkli huni tuzaklarının kiraz ağaçları çiçeklerinde beslenen baklazınnı [Epicometis hirta (Poda) (Coleoptera: Scarabaeidae)]'nın yakalanması üzerine etkisi. Türkiye Entomoloji Bülteni, 3(2), 99-105.

Yașar, B., \& Uysal, O. (2013). Evaluation of the efficacy of different traps in capturing apple blossom beetle (Epicometis hirta (Poda) (Coleoptera: Scarabaeidae). Türkiye Entomoloji Dergisi, 37(2), 169-177.

Yuksel, E., \& Canhilal, R. (2018). Evaluation of local isolates of entomopathogenic nematodes for the management of black cutworm, Agrotis ipsilon Hufnagel (Lepidoptera: Noctuidae). Egyptian Journal of Biological Pest Control, $28(1), 82$.

Yuksel, E., Canhilal, R., \& Imren, M. (2019). Potential of four Turkish isolates of entomopathogenic nematodes against three major stored products insect pests. Journal of Stored Products Research, 83, 317-321. 